\title{
Thinking of Change in terms of 'GAins' OR 'LOSSES': Promotion versus PREVENTION FOCUS AS A MODERATOR IN THE JOB DEMANDS-RESOURCES MODEL
}

\section{Authors:}

Paraskevas Petrou ${ }^{1}$

Evangelia Demerouti ${ }^{2}$

\section{Affiliations:}

${ }^{1}$ Department of Psychology, Utrecht University, The Netherlands

${ }^{2}$ Department of Industrial Engineering and Innovation Sciences, Eindhoven University of Technology, The

Netherlands

Correspondence to:

Paraskevas Petrou

email:

P.Petrou@uu.nl

\section{Postal address:}

PO Box 80140, 3508 TC

Utrecht, The Netherlands

\section{Keywords:}

job characteristics; selfregulation; organisational change; burnout; openness to change

\section{Dates:}

Received: 13 Aug. 2009

Accepted: 16 Nov. 2010

Published: 08 Dec. 2010

How to cite this article: Petrou, P., \& Demerouti, E. (2010). Thinking of change in terms of 'gains' or 'losses': Promotion versus prevention focus as a moderator in the job demands-resources model. SA Journal of Industrial Psychology/SA Tydskrif vir Bedryfsielkunde, 36(2), Art. \#943, 11 pages. DOI: 10.4102/ sajip. v36i2.943

This article is available at: http://www.sajip.co.za

(c) 2010. The Authors. Licensee: OpenJournals Publishing. This work is licensed under the Creative Commons Attribution License.

\section{ABSTRACT}

Orientation: Promotion and prevention regulatory foci have been established as self-regulation systems with implications for the study of change.

Research purpose: The study aimed to test moderating effects of promotion and prevention focus within the job demands-resources model in a context of organisational change. Predictors included job demands and resources whilst outcomes included emotional exhaustion, disengagement and openness to change.

Motivation for the study: The study intended to understand whether individual differences in promotion and prevention focus play an important role during the experience of organisational change.

Research design, approach and method: A sample of 164 teachers from the Netherlands participated in a quantitative survey design before a new governmental policy was implemented in their schools and 189 different teachers working in the same schools participated in the survey after the implementation of the policy. Cross-sectional moderated regression analyses were used to analyse the data.

Main findings: Promotion focus moderated the relationship between job demands and openness to change, whilst both promotion and prevention focus moderated many of the relationships between job resources on the one hand and emotional exhaustion, disengagement and openness to change on the other hand.

Practical/managerial implications: Knowing that organisational change can have different meanings for promotion and prevention focused employees, managers can facilitate employee adaptation to change.

Contribution/value-add: This research provides a theoretical framework that incorporates selfregulation as a moderator in the job demands-resources model. At the same time, implications for organisational change were co-examined.

\section{INTRODUCTION}

During the past several decades several studies have shown that particular job characteristics can be related to certain psychological and behavioural outcomes (for example, see a meta-analysis by Fried and Ferris, 1987; or a review by Schaufeli and Enzmann, 1998). It is generally accepted that job characteristics can be distinguished in job demands and job resources (Schaufeli \& Bakker, 2004). A distinction which is incorporated in the job demands-resources (JD-R) model (Demerouti, Bakker, Nachreiner, \& Schaufeli, 2001; Bakker, Demerouti, De Boer, \& Schaufeli, 2003) proposing that, certain job demands relate primarily to impaired health and energy, whilst certain job resources are primarily related to work engagement; and, that job resources can buffer the impact of job demands on burnout (Bakker, Demerouti, \& Euwema, 2005). The JD-R model has been validated across different occupations (Schaufeli \& Bakker, 2004) and has been tested longitudinally (Mauno, Kinnunen, \& Ruokolainen, 2007). It has also been extended to include personal resources as mediators between job resources and work engagement (Xanthopoulou, Bakker, Demerouti, \& Schaufeli, 2007; 2009).

Up to date the JD-R model has not been tested within a context of organisational change. The aim of the present study is to test and refine the JD-R model within a context of change, by including possible moderators for the basic two processes that are proposed by the model, namely the health impairment process (job demands leading to impaired health) and the motivational process (job resources leading to motivational outcomes). Apart from the two common health and motivational outcomes (namely emotional exhaustion and disengagement), openness to change will also be examined in order to accommodate organisational change. In our attempt to refine the model linking it to organisational change, the Regulatory Focus Theory (Higgins, 1997, 1998) was employed to test whether promotion and prevention as individual regulatory foci can play an important role during changes at the workplace. Although self-regulation has already theoretically been linked to organisational change (Taylor-Bianco, \& Schermerhorn, 2006), the present study would endeavour to verify the link empirically. Regulatory Focus Theory is one of the few motivation and self-regulation theories that allows for equal consideration of the environment and the individual. It also has several implications for emotive responses at the workplace, individual-organisation fit and goal-setting behaviours. Furthermore, the theory explains what type of challenges can motivate individuals, or how organisational changes can hold different meanings for individuals with different motivational tendencies (Brockner \& Higgins, 2001). In this article, we argue that linking the JD-R model to self-regulation within a context of change is of particular importance. 


\section{THE JOB DEMANDS-RESOURCES MODEL}

To a certain extent, the JD-R model (Demerouti et al., 2001; Bakker, Demerouti, De Boer, \& Schaufeli, 2003) was developed in order to address weaknesses of models, such as the DemandControl model (Karasek, 1979) and the Effort-Reward Imbalance model (Siegrist, 1996), by providing a wider 'list' of job demands and resources and the way they relate to health outcomes. The rationale of the JD-R model especially after the incorporation of personal resources (Xanthopoulou et al., 2007), bears a strong resemblance to the basic assumptions of 'fortigenesis' (Strümpfer, 2006): that is, life is characterised by challenge, struggling and suffering due to inherent demands of the human condition, but there are also strengths and forces of resilience to negotiate those demands.

Job demands refer to 'those physical, social, or organisational aspects of the job that require sustained physical or mental effort and are therefore associated with certain physiological and psychological costs' (Demerouti et al., 2001), whereas job resources refer to those:

physical, psychological, social or organizational aspects of the job that may do any of the following: (a) be functional in achieving work goals; (b) reduce job demands at the associated physiological and psychological costs; (c) stimulate personal growth and development.

(Demerouti et al., 2001, p. 501)

One very important premise of the JD-R model is that two distinct psychological processes play a role in the development of job stress and motivation (Bakker \& Demerouti, 2007). Firstly, the health impairment process, through which chronic job demands exhaust employee's mental and physical resources and lead to health problems and emotional exhaustion. In the second process, motivational in nature, job resources have motivational potential and are negatively associated with disengagement. Furthermore, the JD-R model proposes that the interaction of job demands and resources can also play an important role in the development of job strain and motivation. For example, job resources can buffer the impact of job demands on job strain (Bakker, Demerouti, Taris, Schaufeli, \& Schreurs, 2003; Bakker et al., 2005).

However, up to date empirical studies involving the JD-R model primarily focused on work characteristics. Expanding the model, Xanthopoulou et al. $(2007,2009)$ showed that personal resources of employees can also be important determinants of employees' adaptation to the work environment. In particular, they found that job resources predicted personal resources (also at a daily level), which were further linked to work engagement. Xanthopoulou et al. (2007) also hypothesised but did not find that personal resources moderated the relation between job demands and emotional exhaustion. However, there have been change-related studies which demonstrate the moderating effects of individual differences with respect to the relationship between work characteristics and outcomes. For example, high mastery orientation has been shown to reduce the negative relationship between poor change management processes and perceived changes in person-environment fit (Caldwell, Herold, \& Fedor, 2004). Proactive personality can moderate the relationship between access to resources and felt responsibility for constructive change (Fuller, Marler, \& Hester, 2006). Also, change-related self-efficacy moderated the relationship between job stressors and job satisfaction (Jimmieson, Terry, \& Callan, 2004).

Empirical examination of job demands and job resources and their health implications from an organisational change perspective is not new. For example, researchers have studied the health and motivational outcomes of several demands and resources throughout organisational changes. Those include, amongst others: workload, role ambiguity and change-related difficulties (Jimmieson, Terry, \& Callan, 2004; Noblet, Rodwell,
\& McWilliams, 2006), social support (Cunningham, Woodward, Shannon, MacIntosh, Lendrum, Rosenbloom, \& Brown, 2002), job control, role clarity, task identity (Korunka, Scharitzer, Carayon, \& Sainfort, 2003), supervisory support (Verhaeghe, Vlerick, de Backer, van Maele, \& Gemmel, 2008), job autonomy (Hornung \& Rousseau, 2007), communication and participation (Bordia, Hobman, Jones, Gallois, \& Callan, 2004). Job demands and resources have also been related to innovativeness and proactive behaviour (Hakanen, Perhoniemi, \& Topinnen-Tanner, 2008; Salanova \& Schaufeli, 2008; Fritz \& Sonnentag, 2009) but not during actual organisational change. However, most of these studies usually fail to provide an adequate theoretical rationale for the examination of a wide range of demands and resources, or to measure individual variables which can play an important role during changes, in addition to work characteristics.

In the present study the Regulatory Focus Theory developed by Higgins $(1997,1998)$, provides the theoretical basis to measure the role of personal resources within a context of change. The theory postulates that people are motivated by their need to align themselves with differential goals and standards. Therefore, they can attach differential meanings to job demands and job resources alike. This can further affect employee's motivation and health during organisational changes. In the following section we will review individual promotion versus prevention focus as regulatory factors in human functioning and we shall see how these constructs have been theoretically and empirically connected to environmental factors and change.

\section{PROMOTION VERSUS PREVENTION REGULATORY FOCUS}

Regulatory Focus Theory (Higgins, 1997, 1998) distinguishes between two systems of self-regulation: Promotion focused individuals are driven by growth and development needs, they are motivated by their 'ideal selves' (wishes, hopes and aspirations) and are sensitive to the presence or absence of positive outcomes (gains and non-gains). On the other hand, prevention focused individuals are driven by their need for safety; they are motivated by their 'ought selves' (duties, obligations and responsibilities) and are sensitive to the presence or absence of negative outcomes (losses and non-losses). The theory predicts that promotion focus will be associated with tolerance to uncertainty and change, whereas a prevention focus will be associated with safety and stability. In Crowe and Higgins' (1997) research, it was shown that promotion focus was associated with a 'risky' response bias, whereas prevention focus was associated with a 'conservative' response bias. One of the first studies to link regulatory focus directly with change was that of Liberman, Idson, Camacho and Higgins (1999) which indicates that promotion focused individuals demonstrate a preference for change, whilst prevention focused individuals show a preference for stability.

However, promotion and prevention focus have not only been conceptualised as individual factors. Brockner and Higgins (2001) argue that regulatory focus can also be a function of situational factors. They suggest that regulatory cues will be prominent within the incentives provided to individuals, as well as within different leadership styles through the use of different language and symbols. It seems thus, that regulatory cues can be found within situational factors. Such situational factors can be job characteristics, such as job resources, but also job demands. Kark and Van Dijk (2007) theorised that different types of leadership behaviour can foster different regulatory foci in employees. Whilst promotion focus of the leader will promote openness to change, risk taking and an innovation-oriented culture at the group level amongst employees, prevention focus of the leader will promote a preference for stability, risk aversion and a quality-oriented culture at the group level amongst employees. More interestingly, it has been proposed that when the regulatory focus instigated by the environment 
fits the individual regulatory focus, individuals will experience 'regulatory fit' and that this can have a positive effect on motivation and performance (Shah, Higgins, \& Friedman, 1998). Because change is a challenging situation and personorganisation fit has particular motivational implications, it has been argued that perception of regulatory fit at all hierarchical levels of an organisation plays a very important role during organisational changes (Taylor-Bianco, \& Schermerhorn, 2006).

\section{THE PRESENT STUDY}

The central hypothesis of the present study is that the strength of the relationships predicted by the JD-R model (job demands are positively associated with emotional exhaustion and job resources are negatively associated with disengagement) will be different for different levels of individual promotion and prevention focus. Consequently, we focus on outcomes commonly examined by the JD-R model, namely emotional exhaustion and disengagement. Furthermore, because openness to change is an important factor enhancing adaptation to changes at the workplace (Wanberg \& Banas, 2000), we will examine openness to change as an additional outcome next to emotional exhaustion and disengagement. In this way, our design can accommodate more explicitly and comprehensively for change as variable in the organisations under examination. This will be in line with other studies exploring the link between attitudes to change or commitment to change and job demands (Vakola \& Nikolaou, 2005; Jimmieson et al., 2004) or job resources (Hornung \& Rousseau, 2007).

In the present study the proposed interactions were tested in two samples of secondary school teachers. The study started with an investigation of the basic job demands and job resources. In consultation with the project team (including directors and teachers of some of the schools participating in the study) it was decided to take the measurement of workload and student misbehaviour as the most representative job demands of a teacher (this is also consistent with other studies, e.g. Van Horn, Schaufeli, \& Enzmann, 1999) and participation, feedback and leader support as representative of job resources (also see, Hakanen, Bakker, \& Schaufeli, 2006)

\section{Job demands}

As outlined earlier, job demands refer to those aspects of the job that require sustained physical or mental effort and can be associated with physiological and psychological costs and as such health (Demerouti et al., 2001). If we think of regulatory focus not exclusively as an individual construct, but also as a state that can be 'primed' by situational cues (Higgins, Roney, Crowe, \& Hymes, 1994), one can propose that job demands will be more inclined to 'activate' the prevention focus in teachers. Prevention focus is primarily associated with a sense of obligation and responsibility (Higgins, 1997, 1998) and inrole, versus extra-role, performance (Neubert, Kacmar, Carlson, Chonko, \& Roberts, 2008). Consequently, we can expect that teachers who are prevention focused will be experiencing regulatory fit and will 'benefit' more from the prevention cues of job demands. Therefore, it can be expected that they will be better protected against adverse health outcomes of job stressors, than the teachers who are promotion focused. This positive effect may also be reflected in their performance, motivation and, in consequence, openness to change. Openness to change might sound contradictory here because it is generally accepted that prevention focus, as an individual preference, is regularly linked to a conservative tendency (Liberman et al., 1999) and as such resistance to change. However, at the same time it has been shown that change messages can well be framed in a way that emphasises the prevention focus of the message (Latimer et al., 2008). Therefore, prevention focus is not always a 'barrier' to change, but can facilitate change within a prevention focused environment. On the other hand, the opposite pattern of relationships could be expected amongst promotion focused teachers. The primed environmental focus will be inconsistent with their own chronic regulatory preference, thus, leading to the experience of 'misfit'. In other words, promotion focused teachers are likely to experience a 'dissonance' or distress because of the prevention cues of job demands.

Hypothesis 1: The positive relationship between job demands and emotional exhaustion will be stronger for individuals higher in promotion focus and individuals lower in prevention focus compared to their counterparts.

Hypothesis 2: The negative relationship between job demands and openness to change will be stronger for individuals higher in promotion focus and individuals lower in prevention focus compared to their counterparts.

\section{Job resources}

Job resources are not only necessary to deal with the job demands, but they are also important in their own right (Bakker \& Demerouti, 2007). One of the three functions of job resources is the stimulation of personal growth and development (Demerouti et al., 2001). In addition to the previously argued proposed relationship between job demands and regulatory factors, we propose that job resources will primarily 'activate' a promotion focus in teachers. Promotion focus is associated with aspirations, ideals and the need for growth (Higgins, 1997, 1998) and extra-role (versus in-role) behaviour (Neubert et al., 2008). This is consistent with Kark and van Dijk's (2007) theoretical proposition that charismatic leadership, which can be seen as a form of job resource, will mostly 'activate' a promotion focus in employees. Consequently, it can be expected that teachers who are promotion focused will experience regulatory fit. As experience of fit is linked to motivational outcomes (TaylorBianco, \& Schermerhorn, 2006), promotion focused teachers are expected to benefit more from the positive outcomes of job resources and therefore demonstrate lower levels of disengagement and higher levels of openness to change. On the other hand, it is likely that the promotion cues of the job resources will lead prevention focused teachers to experience 'misfit'. In other words, the lack of structure and the freedom that job resources sometimes produce, might be a source of dissonance or distress for prevention focused individuals who prefer structure and concrete responsibilities rather than opportunities to develop themselves.

Hypothesis 3: The negative relationship between job resources and disengagement will be stronger for individuals higher in promotion focus and individuals lower in prevention focus compared to their counterparts.

Hypothesis 4: The positive relationship between job resources and openness to change will be stronger for individuals higher in promotion focus and individuals lower in prevention focus than their counterparts.

\section{RESEARCH DESIGN}

\section{Research approach}

The present research, carried out on two samples of secondary school teachers, was survey-based, quantitative in nature and cross-sectional. An initial two-sample-design was proposed in order to provide for a longitudinal study to determine the influence of organisational change (before and after change groups). The notification and implementation of a new government policy, according to which teachers had to focus on talent development in pupils, served as the context of change variable. Unfortunately it was not possible to test for the longitudinal effect of change on the same sample in a 'before and after' research design, due to the relocation of many teachers between the two testing periods. However, two independent samples were retained. The first sample consisted of teachers who received notification of the new policy, whilst the second 
sample (with no teachers who were involved in the first survey) consisted of teachers who had to implement the new policy of talent development in pupils.

\section{Research method}

\section{Research participants \& procedure}

A total sample of 164 teachers from 7 secondary schools in the Netherlands participated in the first survey and 189 different teachers from the same schools participated in the second survey (12 months after the first survey). The questionnaire had the form of an on-line survey. All teachers received an e-mail with a link to the survey, along with a short description of the study. They were also informed that participation in the study was voluntary and anonymous. Response rate was about $75 \%$ for the first sample and 55\% for the second sample. The first sample included 108 women $(65.9 \%)$ and 56 men (34.1\%). The mean age was $44.6(S D=9.9)$ and the mean tenure was 7.4 years $(S D=$ 6.9). Of the teachers in the first sample, $82 \%$ had been formally notified about the new government policy according to which they would have to focus on talent development in pupils. In the second sample, consisting of teachers implementing the new policy, the mean age was $42.6(S D=10.5)$, the mean tenure was 9 years $(S D=8.3)$ and the respondents were evenly distributed between 92 men $(48.7 \%)$ and 99 women (51.3\%).

\section{Research instruments}

Workload: Workload was measured with 4 items based on a Dutch version (Bakker et al., 2003) of Karasek's (1985) Job Content Instrument. The scale refers to demanding aspects of a job and it was adjusted for the teaching profession. A sample item is 'Do you have much work to do as a teacher?'. Items were scored on a 5 -point Likert-type scale ranging from ' 1 = never' to ' 5 = always'. Cronbach's alpha was 0.82 for the first sample and 0.89 for the second sample.

Student Misbehaviour: Student misbehaviour was measured with a 6-item scale adapted from Kyriacou and Sutcliffe (1978). The respondents were asked to indicate the severity of stress caused by certain stress factors, such as 'noisy students' and 'pupils who show a lack of interest'. The items were scored on a 5 -point Likert-type scale ranging from ' $1=$ no stress' to ' $5=$ extreme stress'. Cronbach's alpha was 0.90 for the first sample and 0.88 for the second sample.

Feedback: Feedback was measured with three items of the Job Diagnostic Survey (Hackman \& Oldham, 1980). A Dutch version of the items has been used by Demerouti (2006). The items were adjusted for the teaching profession. Items were scored on a 5-point Likert-type scale ranging from ' $1=$ never' to ' $5=$ always'. A sample item is 'I get sufficient information about the results of my work as a teacher'. Cronbach's alpha was 0.82 for the first sample and 0.89 for the second sample.

Participation: The measurement of participation in change was based on a 4-item scale constructed by Wanberg and Banas (2000). All the items were adjusted to accommodate the specific change variable of the study, using the phrase 'Talent Development' ('Talentvol ontwikkelen') to refer to the new policy introduced to secondary schools. A sample item is 'If I want to, I can have input into the decisions being made about the Talent Development'. The items were scored on a 5-point Likerttype scale ranging from ' $1=$ never' to ' $5=$ always'. Cronbach's alpha was 0.75 for the fist sample and 0.83 for the second sample.

Leader support: Leader support was measured with the 7-point leader-member exchange scale developed by Janssen and Van Yperen (2004). Items were scored on a 5-point Likert-type scale ranging from ' $1=$ never' to ' $5=$ always'. A sample item is 'My supervisor would personally be inclined to help me solve problems in my work'. Cronbach's alpha was 0.93 for the first sample and 0.95 for the second sample.
Individual Regulatory focus: Regulatory focus of respondents was measured with the 18-item Promotion/Prevention scale constructed by Lockwood, Jordan and Kunda (2002) adjusted for teachers. In the first sample we used the two 9-item scales to measure promotion and prevention focus. Items were scored on a 5-point Likert type scale ranging from '1 = seldom/ never' to ' 5 = to a great extent'. A sample item for promotion focus is 'I often think about how I will achieve success in my work as a teacher' and a sample item for prevention focus is 'I frequently think about how I can prevent failures at school'. In the second sample we used short versions of the scales based on the reliability coefficients of the original scales used in the first sample. We, thus, decided to use a 7-item scale for prevention focus and a 6-item scale for promotion focus. Cronbach's alpha for promotion focus was 0.70 in the first sample and 0.76 in the second sample. For the prevention focus it was 0.69 in the first sample and 0.70 in the second sample.

Burnout: Burnout was measured with the Oldenburg Burnout Inventory (Demerouti et al., 2001; 2003). Items were scored on a 4-point Likert-type scale ranging from ' 1 = totally disagree' to ' 4 = totally agree'. Emotional exhaustion was measured with 8 items, of which four items were positively worded and four were negatively worded. Sample items are: 'After my work, I usually feel worn out and weary' and 'After work, I have enough energy for my leisure activities' (reversed). Cronbach's alpha was 0.87 for the first sample and 0.78 for the second sample. Disengagement was measured with 8 items. Similarly, four items were positively worded and four were negatively worded. Sample items are: 'It happens more and more often that I talk about my work in a negative way' and 'I feel more and more engaged in my work' (reversed). Cronbach's alpha was 0.78 for the first sample and 0.79 for the second sample.

Openness to change: Openness to change was measured with a 10-item scale developed by Miller, Johnson and Grau (1994) adjusted for the specific change variable of this study. Items were scored on a 5-point Likert-type scale ranging from ' 1 = totally disagree' to ' $5=$ totally agree'. A sample item is 'I consider myself open to the changes Talent Development is going to bring about in my role at work'. Cronbach's alpha was 0.86 for the first sample and 0.89 for the second sample.

\section{Statistical Analysis}

To test our interaction hypotheses, moderated regression analyses were applied using SPSS regression. All the two-way interaction effects were tested separately for every job demand and every job resource, resulting in a series of 20 hierarchical regression analyses for two outcomes (namely, emotional exhaustion and openness to change for job demands and disengagement and openness to change for job resources). In all the first steps we entered the independent variable along with the moderator and in the second steps we entered all centered interaction terms (Aiken \& West, 1991). Prior to the analyses, all variables were screened for normality. The majority of the variables had skewness between \pm 2 and kurtosis between \pm 3.29 , meeting the accepted criteria for normality (Tabachnick \& Fidell, 2000). The assumptions for regression analysis (homoscedasticity, absence of multicollinearity, independent errors and linearity) were also met.

\section{RESULTS}

Table 1 and Table 2 show the means (with standard deviations) and intercorrelations between the study variables for the first and the second sample respectively. Job demands demonstrate moderate to high correlations with emotional exhaustion in both samples with $|0.28|<r<|0.52|(p<0.01)$. The relationships between job resources and disengagement within the two samples varied from non-significant to moderate negative relationships (e.g. -0.27, $p<0.001$, between disengagement and feedback in the second sample). Relationships between 
TABLE 1

Means, standard deviations and correlations between the variables in Sample $1(N=164)$

\begin{tabular}{|c|c|c|c|c|c|c|c|c|c|c|c|}
\hline Variable & $M$ & $S D$ & 1 & 2 & 3 & 4 & 5 & 6 & 7 & 8 & 9 \\
\hline 1. Workload & 3.62 & 0.75 & & & & & & & & & \\
\hline 2. Student misbehaviour & 2.05 & 0.78 & 0.02 & & & & & & & & \\
\hline 3. Feedback & 2.61 & 0.75 & 0.05 & -0.05 & & & & & & & \\
\hline 4. Participation & 2.61 & 0.85 & $-0.18^{*}$ & 0.00 & 0.07 & & & & & & \\
\hline 5. Leader support & 2.90 & 0.81 & -0.01 & 0.03 & $0.31^{\star \star *}$ & 0.15 & & & & & \\
\hline 6. Promotion focus & 2.96 & 0.51 & $0.19^{*}$ & $-0.21^{\star *}$ & -0.04 & 0.08 & $0.17^{*}$ & & & & \\
\hline 7. Prevention focus & 2.03 & 0.47 & $0.21^{* *}$ & $0.23^{\text {** }}$ & 0.02 & 0.05 & $0.15^{*}$ & $0.34^{* * *}$ & & & \\
\hline 8. Emotional exhaustion & 2.33 & 0.52 & $0.52^{* \star *}$ & $0.31^{* \star *}$ & -0.09 & -0.15 & -0.14 & -0.09 & $0.24^{\star *}$ & & \\
\hline 9. Disengagement & 2.17 & 0.44 & $0.24^{\star *}$ & $0.24^{* *}$ & -0.04 & -0.09 & $-0.24^{* *}$ & -0.09 & $0.20^{*}$ & $0.60^{* * *}$ & \\
\hline 10. Openness to change & 3.36 & 0.70 & $-0.24^{\star *}$ & $-0.15^{\star}$ & 0.01 & $0.40^{* * *}$ & 0.12 & 0.13 & -0.15 & $-0.30^{\star \star \star}$ & $-0.40^{* \star *}$ \\
\hline
\end{tabular}

${ }^{*}, p \leq 0.05 ;{ }^{* *}, \mathrm{p} \leq 0.01 ;{ }^{* \star *}, p \leq 0.001, M$, mean; $S D$, standard deviation

TABLE 2

Means, standard deviations and correlations between the variables in Sample $2(N=189)$

\begin{tabular}{|c|c|c|c|c|c|c|c|c|c|c|c|}
\hline Variable & $M$ & $S D$ & 1 & 2 & 3 & 4 & 5 & 6 & 7 & 8 & 9 \\
\hline 1. Workload & 3.62 & 0.88 & - & - & - & - & - & - & - & - & - \\
\hline 2. Student misbehaviour & 2.02 & 0.74 & -0.06 & - & - & - & - & - & - & - & - \\
\hline 3. Feedback & 2.65 & 0.90 & 0.06 & -0.14 & - & - & - & - & - & - & - \\
\hline 4. Participation & 2.66 & 0.94 & -0.05 & 0.02 & 0.07 & - & - & - & - & - & - \\
\hline 5. Leader support & 2.85 & 0.96 & 0.00 & $-0.20^{\star *}$ & $0.23^{* *}$ & $0.17^{*}$ & - & - & - & - & - \\
\hline 6. Promotion focus & 3.30 & 0.64 & $0.17^{*}$ & -0.11 & $0.15^{*}$ & $0.16^{*}$ & $0.23^{\star \star \star}$ & - & - & - & - \\
\hline 7. Prevention focus & 2.15 & 0.58 & 0.06 & 0.11 & 0.02 & -0.05 & -0.11 & $0.23^{* \star *}$ & - & - & - \\
\hline 8. Emotional exhaustion & 2.26 & 0.46 & $0.46^{\star *}$ & $0.28^{\star * *}$ & $-0.19^{\star \star}$ & -0.09 & -0.13 & -0.09 & $0.24^{\star \star *}$ & - & - \\
\hline 9. Disengagement & 2.18 & 0.49 & 0.08 & $0.23^{* * *}$ & $-0.27^{\star \star \star}$ & -0.02 & $-0.16^{*}$ & $-0.31^{\text {***}}$ & 0.07 & $0.48^{* * *}$ & - \\
\hline 10. Openness to change & 3.31 & 0.70 & -0.07 & $-0.17^{\star}$ & -0.01 & $0.34^{\star \star *}$ & $0.17^{*}$ & $0.26^{\star \star *}$ & -0.01 & $-0.24^{\star \star \star}$ & $-0.43^{\text {***}}$ \\
\hline
\end{tabular}

${ }^{*}, p \leq 0.05 ;{ }^{* *}, p \leq 0.01 ;{ }^{* * \star}, p \leq 0.001 ; M$, mean; $S D$, standard deviation

TABLE 3

Regression of emotional exhaustion and openness to change on job demands, promotion and prevention focus in sample $1(N=164)$

\begin{tabular}{|c|c|c|c|c|c|c|c|}
\hline \multirow[b]{2}{*}{ Step } & \multirow[b]{2}{*}{ Model } & \multicolumn{3}{|c|}{ Emotional Exhaustion } & \multicolumn{3}{|c|}{ Openness to Change } \\
\hline & & $\beta$ & $\Delta R 2$ & $\Delta F$ & $\beta$ & $\Delta R 2$ & $\Delta F$ \\
\hline \multirow[t]{2}{*}{1} & Promotion focus & $-0.20^{\star *}$ & - & - & $0.17^{*}$ & - & - \\
\hline & Workload & $0.55^{\star \star \star}$ & 0.30 & $35.03^{\star \star \star}$ & $-0.28^{\star \star \star}$ & 0.09 & $7.85^{\star \star *}$ \\
\hline 2 & Promotion focus $\times$ Workload & 0.00 & 0.00 & 0.00 & -0.10 & 0.01 & 1.81 \\
\hline \multirow[t]{2}{*}{1} & Prevention focus & 0.13 & - & - & -0.10 & - & - \\
\hline & Workload & $0.49^{* \star *}$ & 0.28 & $31.85^{\star \star \star}$ & $-0.22^{\star \star}$ & 0.07 & $5.67^{\star *}$ \\
\hline 2 & Prevention focus $\times$ Workload & -0.04 & 0.00 & 0.37 & 0.01 & 0.00 & 0.02 \\
\hline \multirow[t]{2}{*}{1} & Promotion focus & -0.02 & - & - & 0.08 & - & - \\
\hline & Student Misbehaviour & $0.31^{* \star *}$ & 0.10 & $8.82^{\star \star \star}$ & $-0.16^{*}$ & 0.03 & 2.84 \\
\hline 2 & Promotion focus $\times$ Student Misbehaviour & 0.02 & 0.00 & 0.08 & $-0.18^{*}$ & 0.03 & $5.20^{*}$ \\
\hline \multirow[t]{2}{*}{1} & Prevention focus & $0.17^{*}$ & - & - & -0.10 & - & - \\
\hline & Student Misbehaviour & $0.27^{\star \star \star}$ & 0.13 & $11.66^{\star \star \star}$ & -0.12 & 0.04 & 3.04 \\
\hline 2 & Prevention focus $\times$ Student Misbehaviour & 0.01 & 0.00 & 0.02 & -0.07 & 0.01 & 0.84 \\
\hline
\end{tabular}

job demands or resources and openness to change within the samples also varied from non-significant to moderate. The highest was that between openness to change and participation: $0.40(p<0.001)$ in the fist sample and $0.34(p<0.001)$ in the second sample.

Tables 3 and 4 show the results of the moderated regression analyses with job demands as independent variables and emotional exhaustion and openness to change as dependent variables for the first and second sample respectively. No interaction terms were found significant for the relationship between job demands and emotional exhaustion; hence Hypothesis 1 was not confirmed. Regarding the next hypothesis, the interaction term of promotion focus and student misbehaviour was significant, in the hypothesised direction (see Figure 1), for openness to change in the first sample $(\beta=0.17$, $p<0.05$ ), providing only partial support to Hypothesis 2 . This implies that only for teachers high in promotion focus, higher student misbehaviour was associated with less openness to change.
Tables 5 and 6 show the results for the moderated regression analyses with job resources as independent variables and disengagement and openness to change as dependent variables for the first and the second sample respectively. Hypothesis 3 was partially supported in the expected direction: In the first sample, the negative relationship between feedback and disengagement was stronger for individuals high in promotion focus ( $\beta=-0.19, p<0.05$ ) (see Figure 2$)$. In the second sample the relationship was weak for individuals high in prevention focus, but strong for individuals low in prevention focus ( $\beta$ $=0.60, p<0.01$ ) (see Figure 3). Also, in the second sample, in contrast to our expectations, the negative relationship between leader support and disengagement was stronger for individuals high in prevention focus $(\beta=-0.23, p<0.001$ ) (see Figure 4 ), but as hypothesised it was also stronger for individuals high in promotion focus $(\beta=-0.16, p<0.01$ ) (see Figure 5 ).

Hypothesis 4 was partially supported. In the first sample the positive relationship between participation and openness to change was stronger for individuals high in promotion focus 
TABLE 4

Regression of emotional exhaustion and openness to change on job demands, promotion and prevention focus in sample $2(N=189)$

\begin{tabular}{|c|c|c|c|c|c|c|c|}
\hline \multirow[b]{2}{*}{ Step } & \multirow[b]{2}{*}{ Model } & \multicolumn{3}{|c|}{ Emotional Exhaustion } & \multicolumn{3}{|c|}{ Openness to Change } \\
\hline & & $\beta$ & $\Delta R 2$ & $\Delta F$ & $\beta$ & $\Delta R 2$ & $\Delta F$ \\
\hline \multirow[t]{2}{*}{1} & Promotion focus & $-0.18^{\star \star}$ & - & - & $0.30^{\star \star \star}$ & - & - \\
\hline & Workload & $0.49^{\star * *}$ & 0.24 & $29.13^{\star \star *}$ & -0.12 & 0.08 & $8.34^{* * *}$ \\
\hline 2 & Promotion focus $\times$ Workload & -0.03 & 0.00 & 0.22 & 0.12 & 0.01 & 2.65 \\
\hline \multirow[t]{2}{*}{1} & Prevention focus & $0.21^{* * *}$ & - & - & 0.00 & - & - \\
\hline & Workload & $0.44^{* * *}$ & 0.25 & $31.47^{\star \star \star}$ & -0.07 & 0.01 & 0.50 \\
\hline 2 & Prevention focus $\times$ Workload & -0.1 & 0.01 & 2.35 & 0.03 & 0.00 & 0.13 \\
\hline \multirow[t]{2}{*}{1} & Promotion focus & -0.07 & - & - & $0.25^{\star \star \star}$ & - & - \\
\hline & Student Misbehaviour & -0.12 & 0.02 & 2.05 & -0.14 & 0.09 & $8.86^{\star \star *}$ \\
\hline 2 & Promotion focus $\times$ Student Misbehaviour & -0.01 & 0.00 & 0.01 & 0.04 & 0.00 & 0.32 \\
\hline \multirow[t]{2}{*}{1} & Prevention focus & $0.21^{* \star}$ & - & - & 0.01 & - & - \\
\hline & Student Misbehaviour & $0.26^{\star \star *}$ & 0.12 & $13.21^{\text {***}}$ & $-0.17^{*}$ & 0.03 & 2.65 \\
\hline 2 & Prevention focus $\times$ Student Misbehaviour & 0.07 & 0.01 & 1.06 & 0.05 & 0.00 & 0.43 \\
\hline
\end{tabular}

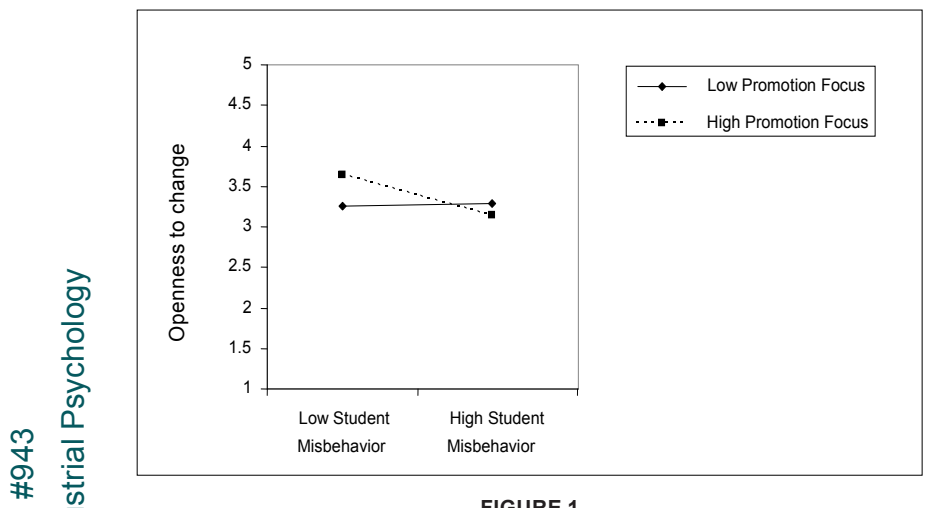

Promotion focus moderating the relationship between student misbehaviour and openness to change in sample 1

$(\beta=0.17, p<0.01)$ (see Figure 6), but contrary to our expectations it was also stronger for individuals high in prevention focus $(\beta=0.16, p<0.01)$ (see Figure 7$)$. In the second sample, as hypothesised, it was stronger for individuals low in prevention focus $(\beta=-0.15, p<0.05)$ (see Figure 8 ).

\section{DISCUSSION}

The aim of the present study was to examine whether promotion and prevention focus as personal regulatory factors can moderate the relationship between job demands-resources on the one hand and burnout and openness to change on the other hand. No interaction term was found significant for the relationships between job demands and emotional exhaustion and only one interaction term involving promotion focus was significant for the relationship between student misbehaviour and openness to change. Regarding job resources, both promotion and prevention focus moderated the relationships between feedback and disengagement, between leader support and disengagement and between participation and openness to change.

The lack of findings in relation to job demands might seem confusing at first sight. However, Xanthopoulou et al. (2006) found that personal resources did not offset the relationship between job demands and emotional exhaustion, but only mediated the link between job resources and work engagement. In other words, it might be the case that due to the intensity of job demands it is unlikely that the health process of the JD-R model can be moderated by individual variables. However, this might not be the case for the disengagement path, which (due to its motivational nature) can allow personal factors to play a role in the development of outcomes. As expected, student misbehaviour was negatively related to openness to change before the implementation of changes, more so for teachers who reported high promotion focus. One can therefore conclude, that the teachers who are promotion focused, being motivated by their wishes, hopes, aspirations and ideals (Higgins 1997, 1998) are discouraged by a noisy and disrespectful classroom and that they might actually be disillusioned in their idealistic expectations. Consequently, they are less eager to embrace changes, as their motivation has been challenged. The reason why this effect was not significant in the second sample may be due to the fact that promotion focused teachers were intrigued by the new opportunities created by the actual implementation of the changes. Therefore, their motivation could have been restored.

Regarding the job resources, it was found as expected that the negative link between feedback and disengagement was stronger for teachers high in promotion focus, but only in the first sample and also stronger for teachers low in prevention focus, but only in the second sample. It has been argued that feedback can prime both promotion and prevention foci in individuals (Roney, Higgins, \& Shah, 1995; Brockner \& Higgins, 2001). However, this should mainly be interpreted in terms of promotion and prevention focused individuals' differential preference for positive and negative feedback respectively. In our study we did not measure perceptions of positive or negative feedback, but rather received feedback per se. It is, thus, reasonable to assume that promotion focused individuals, being motivated by their need for advancement and development (Higgins, 1997, 1998) will benefit more from received feedback than prevention focused individuals.

The two findings regarding leader support only occurred in the second sample, during the implementation of changes and initially seem contradictory. The relationship between leader support and disengagement was strong and negative both for teachers high in promotion focus and teachers high in prevention focus. That is, both promotion and prevention focused teachers benefit equally from a supportive leader. Brockner and Higgins (2001) have argued that organisational authorities can serve as role models, or use language and symbols that can prime differential regulatory foci in employees. For example, Kark and van Dijk (2007) argued that whilst charismatic or transformational leadership is priming more a promotion focus in followers, monitoring and transactional leadership is priming more a prevention focus. In the present study we conceptualised leader support as leader-member exchange. It might well be the case that both promotion and prevention focused employees experience in different ways a quality relationship with their supervisor which can prime foci in accordance with their chronic preferences. If during changes leaders approach employees and introduce changes to them in a way that is more consistent with their own needs and chronic regulatory focus (maybe by 
TABLE 5

Regression of disengagement and openness to change on job resources, promotion and prevention focus in sample $1(N=164)$

\begin{tabular}{|c|c|c|c|c|c|c|c|}
\hline \multirow[b]{2}{*}{ Step } & \multirow[b]{2}{*}{ Model } & \multicolumn{3}{|c|}{ Disengagement } & \multicolumn{3}{|c|}{ Openness to Change } \\
\hline & & $\beta$ & $\Delta R 2$ & $\Delta F$ & $\beta$ & $\Delta R 2$ & $\Delta F$ \\
\hline \multirow[t]{2}{*}{1} & Promotion focus & -0.08 & - & - & 0.13 & - & - \\
\hline & Feedback & -0.02 & 0.01 & 0.78 & 0.02 & 0.02 & 1.44 \\
\hline 2 & Promotion focus $\times$ Feedback & $-0.19^{*}$ & 0.04 & $6.20^{*}$ & -0.02 & 0.00 & 0.05 \\
\hline \multirow[t]{2}{*}{1} & Prevention focus & $0.20^{*}$ & - & - & -0.14 & - & - \\
\hline & Feedback & -0.04 & 0.04 & $3.37^{*}$ & 0.01 & 0.02 & 1.74 \\
\hline 2 & Prevention focus $\times$ Feedback & -0.06 & 0.00 & 0.50 & -0.08 & 0.01 & 1.06 \\
\hline \multirow[t]{2}{*}{1} & Promotion focus & -0.08 & - & - & 0.11 & - & - \\
\hline & Participation & -0.08 & 0.01 & 1.16 & $0.37^{\star \star \star}$ & 0.17 & $16.20^{\star \star \star}$ \\
\hline 2 & Promotion focus $\times$ Participation & -0.01 & 0.00 & 0.02 & $0.17^{*}$ & 0.03 & $5.58^{*}$ \\
\hline \multirow[t]{2}{*}{1} & Prevention focus & $0.20^{*}$ & - & - & $-0.18^{*}$ & - & - \\
\hline & Participation & -0.09 & 0.05 & $4.01^{*}$ & $0.42^{\star \star \star}$ & 0.18 & $18.14^{\star \star \star}$ \\
\hline 2 & Prevention focus $\times$ Participation & 0.01 & 0.00 & 0.02 & $0.16^{*}$ & 0.03 & $5.25^{\star}$ \\
\hline \multirow[t]{2}{*}{1} & Promotion focus & -0.05 & - & - & 0.12 & - & - \\
\hline & Leader support & $-0.23^{* *}$ & 0.06 & $4.95^{\star *}$ & 0.10 & 0.03 & 2.16 \\
\hline 2 & Promotion focus $\times$ Leader support & -0.09 & 0.01 & 1.36 & 0.05 & 0.00 & 0.35 \\
\hline \multirow[t]{2}{*}{1} & Prevention focus & $0.25^{\star \star}$ & - & - & $-0.17^{*}$ & - & - \\
\hline & Leader support & $-0.28^{\star \star}$ & 0.11 & $10.02^{\star \star \star}$ & 0.14 & 0.04 & $3.38^{*}$ \\
\hline 2 & Prevention focus $\times$ Leader support & -0.05 & 0.00 & 0.45 & 0.00 & 0.00 & 0.00 \\
\hline
\end{tabular}

TABLE 6

Regression of disengagement and openness to change on job resources, promotion and prevention focus in sample $2(N=189)$

\begin{tabular}{|c|c|c|c|c|c|c|c|}
\hline \multirow[b]{2}{*}{ Step } & \multirow[b]{2}{*}{ Model } & \multicolumn{3}{|c|}{ Disengagement } & \multicolumn{3}{|c|}{ Openness to Change } \\
\hline & & $\beta$ & $\Delta R 2$ & $\Delta F$ & $\beta$ & $\Delta R 2$ & $\Delta F$ \\
\hline \multirow[t]{2}{*}{1} & Promotion focus & $-0.27^{\text {***}}$ & - & - & $0.27^{\star \star \star}$ & - & - \\
\hline & Feedback & $-0.22^{* *}$ & 0.14 & $15.53^{\star \star *}$ & -0.05 & 0.07 & $7.08^{* * *}$ \\
\hline 2 & Promotion focus $\times$ Feedback & 0.00 & 0.00 & 0.00 & 0.00 & 0.00 & 0.00 \\
\hline \multirow[t]{2}{*}{1} & Prevention focus & $-0.49^{*}$ & - & - & 0.02 & - & - \\
\hline & Feedback & $-0.30^{\star \star \star}$ & 0.08 & $7.72^{\star * *}$ & -0.01 & 0.00 & 0.01 \\
\hline 2 & Prevention focus $\times$ Feedback & $0.60^{\star *}$ & 0.04 & $7.23^{* *}$ & -0.03 & 0.00 & 0.01 \\
\hline \multirow[t]{2}{*}{1} & Promotion focus & $-0.32^{\star \star \star}$ & - & - & $0.22^{\star \star \star}$ & - & - \\
\hline & Participation & 0.02 & 0.10 & $9.71^{\star * *}$ & $0.31^{\star \star *}$ & 0.16 & $17.18^{* * *}$ \\
\hline 2 & Promotion focus $\times$ Participation & -0.04 & 0.00 & 0.29 & 0.08 & 0.01 & 1.46 \\
\hline \multirow[t]{2}{*}{1} & Prevention focus & 0.06 & - & - & 0.03 & - & - \\
\hline & Participation & -0.02 & 0.01 & 0.46 & $0.33^{\star * *}$ & 0.11 & $11.77^{\star \star *}$ \\
\hline 2 & Prevention focus $\times$ Participation & 0.06 & 0.00 & 0.65 & $-0.15^{*}$ & 0.02 & $4.52^{*}$ \\
\hline \multirow[t]{2}{*}{1} & Promotion focus & $-0.26^{\star * *}$ & - & - & $0.22^{\star \star}$ & - & - \\
\hline & Leader support & -0.07 & 0.10 & $10.62^{\star \star *}$ & 0.09 & 0.08 & $8.11^{\star \star \star}$ \\
\hline 2 & Promotion focus $\times$ Leader support & $-0.16^{\star \star}$ & 0.03 & $5.32^{*}$ & 0.14 & 0.02 & 3.53 \\
\hline \multirow[t]{2}{*}{1} & Prevention focus & 0.01 & - & - & 0.01 & - & - \\
\hline & Leader support & $-0.17^{\star \star}$ & 0.03 & 2.79 & $0.17^{\star}$ & 0.03 & 2.70 \\
\hline 2 & Prevention focus $\times$ Leader support & $-0.23^{\star \star \star}$ & 0.05 & $10.62^{\star \star *}$ & 0.02 & 0.00 & 0.05 \\
\hline
\end{tabular}




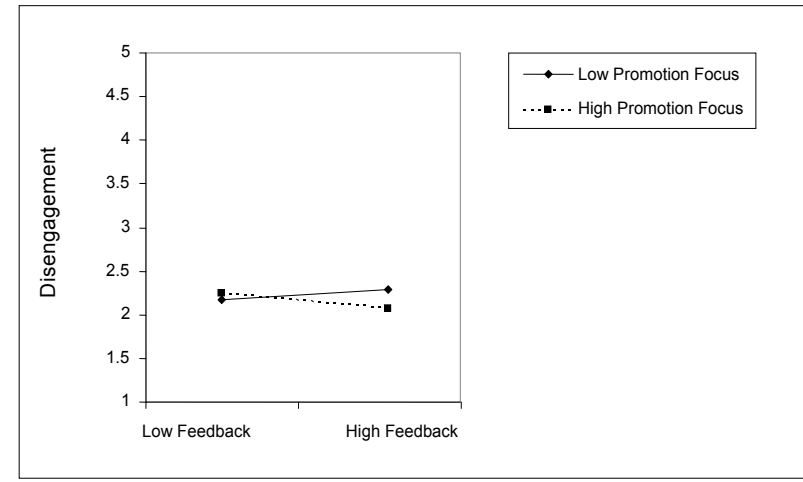

FIGURE 2

Promotion focus moderating the relationship between feedback and disengagement in sample 1

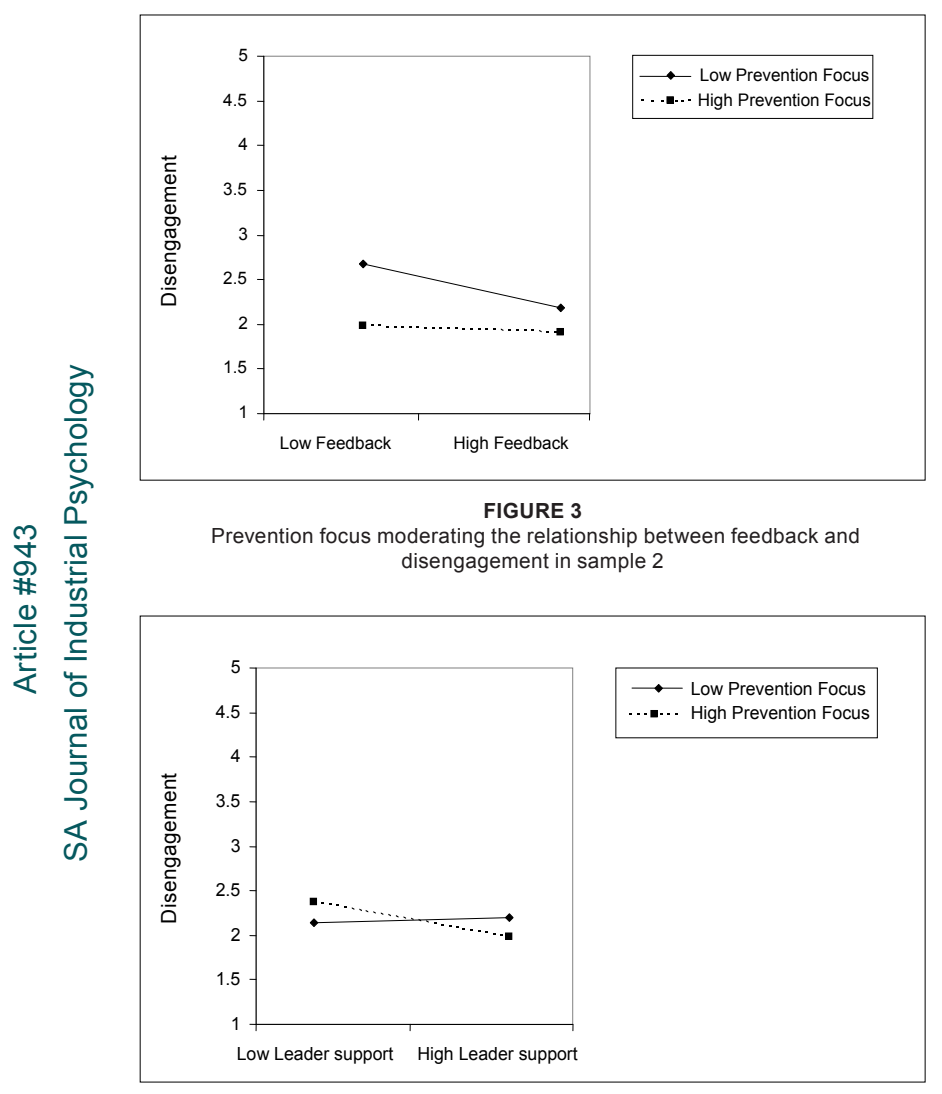

FIGURE 4

Prevention focus moderating the relationship between leader support and disengagement in sample 2

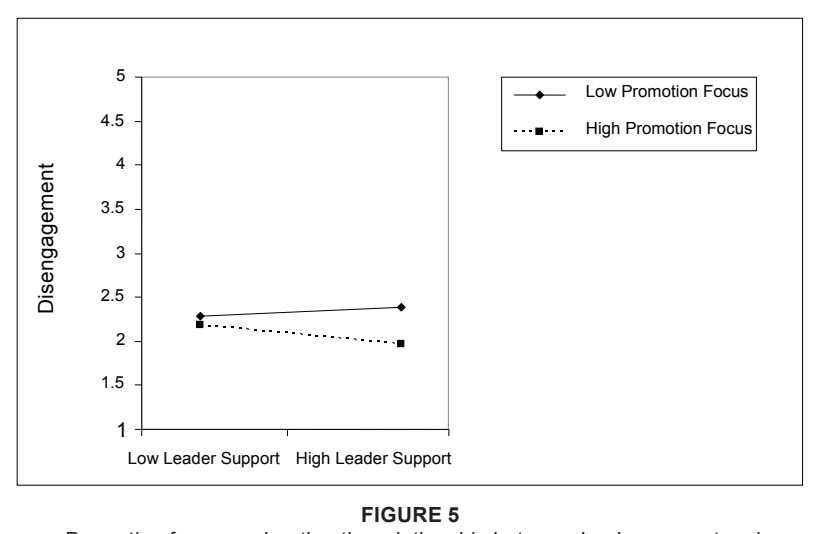

Promotion focus moderating the relationship between leader support and disengagement in sample 2

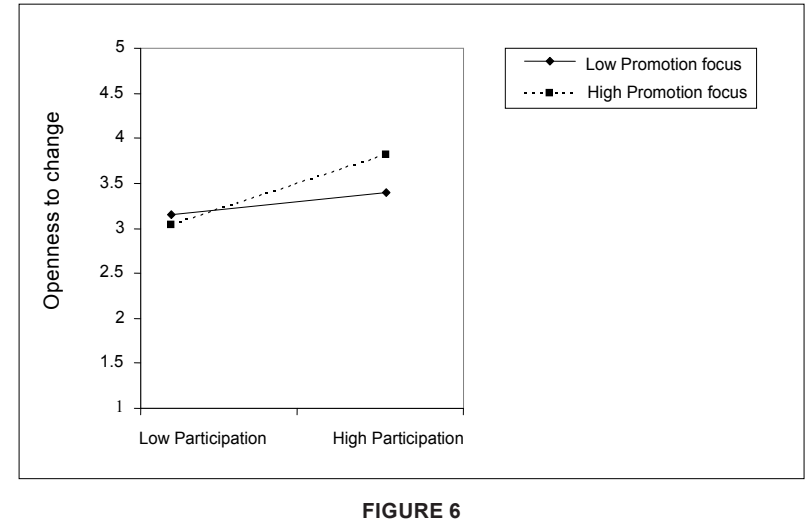

Promotion focus moderating the relationship between participation and openness to change in sample 1

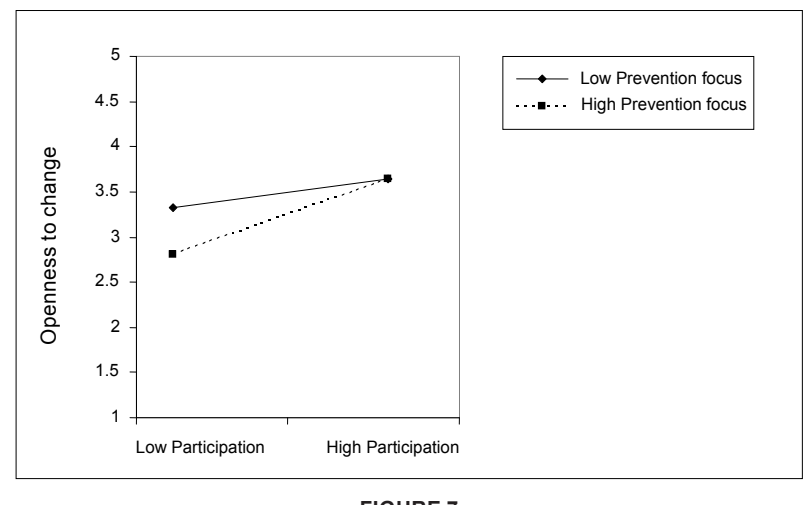

Prevention focus moderating the relationship between participation and openness to change in sample 1

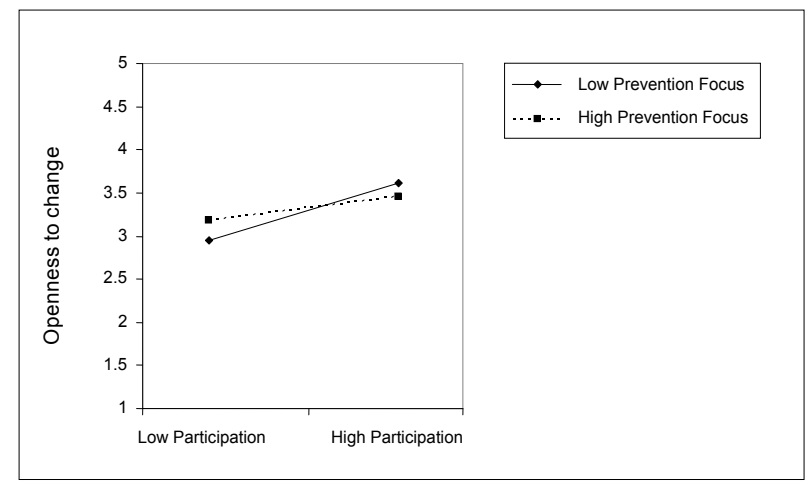

FIGURE 8

Prevention focus moderating the relationship between participation and openness in sample 2

priming differential foci) it is then less striking that this pattern was only found in the second sample.

In line with the findings about leader support, the positive link between participation in changes and openness to change was enhanced both by high promotion and high prevention focus teachers in the first sample. Tseng and Kang (2008) showed that both promotion and prevention focus were positively related to uncertainty towards change. Although this finding is not consistent with our findings, it is worth noting that Tseng and Kang (2008) also found the same pattern of relationship for both foci. Maybe highly promotion and prevention focused individuals can become more open to change by experiencing an opportunity to participate in it. However, when the changes are actually introduced and are implemented, felt responsibility can be higher in prevention focused individuals and participation might impede their motivation. Indeed, in the second sample, 
during the implementation of changes, the positive link between participation in changes and openness to change was less strong for teachers high in prevention focus.

\section{Contribution and limitations of the study}

The present study contributed to the literature in several ways. Firstly, this study retested and refined the JD-R model within a context of change by including an important individual factor of motivational nature as a moderator. Secondly, possible applications of the Regulatory Focus theory to organisational change were examined empirically. The rationale of this examination was based on the conceptualisation of the work environment according to the JD-R model. Thirdly, we did not only examine the implications of self-regulatory focus (i.e. promotion focus or prevention focus) of employees in organisations which are going to experience change, but also after actual changes were implemented. Promotion and prevention focus did manage to explain the strength of the relationship between several job characteristics and outcomes like disengagement, openness to change and, to a lesser extent, emotional exhaustion. In this way, the study contributed to establishing a conceptual and empirical link between selfregulation and organisational change.

Nonetheless there are also limitations in the present study which should be noted. Firstly, the data relied exclusively on self-report measures and no other sources of information were used. Secondly, the sample is representative of seven secondary schools and cannot be generalised across other populations or cultures. Thirdly, the reliabilities of the regulatory focus instruments were not particularly high. Especially the reliability of the prevention focus scale was marginal and this could have affected the results. Further research should preferably use validated measures for individual regulatory focus. Finally, the present design was cross-sectional and thus causal relationships are not to be inferred. The reliance on cross-sectional selfreported data in this study may have inflated our results through common methods bias, although it does not invalidate research findings (Doty \& Glick, 1998). Therefore, the second sample that was collected after the implementation of changes was seen as an independent sample of participants and no comparisons could be made with the first sample which was collected before the changes were implemented. It is worth noting, however, that the study was initially aimed to be longitudinal. Perhaps uncertainty or imposed new demands during organisational changes made individuals less willing to participate in further surveys, therefore the same participants could not be found for the two samples in order to do a longitudinal study.

\section{Implications}

The findings of the study indicated that individual regulatory focus can moderate the motivational and energy processes proposed by the JD-R model. This may have implications for research and practice alike. Firstly, a great part of the literature describing the work environment using the JD-R model does not include personal variables as moderators or mediators in the model. Perhaps, we should acknowledge the role of individual factors in order to have a more comprehensive conception of how job demands and job resources affect employee's health and motivation. Furthermore, in the present study regulatory fit was used as a theoretical background to form hypotheses, but was not measured empirically. At the moment there are no validated or widely used measures of situational regulatory focus, or regulatory framing of introduced organisational changes. We argue that the co-examination of both individual and situational regulatory focus within the same research design will enhance the understanding of employee's willingness to facilitate organisational changes.

Furthermore, implications for management practice should be noted. It might be the case that job demands are not very easily buffered by personal factors. However, job resources can be used to 'activate' employees' regulatory foci which are consistent with their own chronic regulatory foci. Resources like feedback or supervisory support are undoubtedly important for any employee. However, they can be used by different employees to respond to different needs. During changes, prevention focused employees might want to know how the change will help them to avoid loss or to perform duties adequately. For promotion focused employees, on the other hand, it might be more important to know how the change can be used to achieve gains or experience new challenges and to pursue their ideals. Therefore, a manager can use promotion and prevention framings interchangeably to facilitate adaptation to changes for employees with different chronic preferences.

In conclusion, it has to be stressed that regulatory focus and fit concerns human potential. It would be a misconception to think that there are positive and negative ways in which people regulate their behaviour. But an environment that does not accommodate individuals' differential needs can be seen as dysfunctional. Nurturing and responding to an individual's own motivational style in order to facilitate adaptation, means focusing on strengths and already existing potential instead of 'curing' faulty tendencies and procedures. We believe that this is an important purpose that (positive) psychology should serve.

\section{REFERENCES}

Aiken, L.S., \& West, S.G. (1991). Multiple regression: Testing and interpreting interactions. London: Sage Publications.

Bakker, A. B., \& Demerouti, E. (2007). The Job DemandsResources model: state of the art. Journal of Managerial Psychology, 22, 309-328.

Bakker, A.B., Demerouti, E., De Boer, E., \& Schaufeli, W.B. (2003). Job demands and job resources as predictors of absence duration and frequency. Journal of Vocational Behavior, 62, 341-356.

Bakker, A.B., Demerouti, E., \&Euwema, M.C.(2005). Job resources buffer the impact of job demands on burnout. Journal of Occupational Health Psychology, 10, 170-180.

Bakker, A.B., Demerouti, E., Taris, T., Schaufeli, W.B., \& Schreurs, P. (2003). A multi-group analysis of the job demands-resources model in four home care organizations. International Journal of Stress Management, 10, 16-38.

Bakker, A.B., Demerouti, E. \& Verbeke, W. (2004). Using the Job Demands-Resources model to predict burnout and performance. Human Resource Management, 43, 83104.

Bordia, P., Hobman, E., Jones, E., Gallois, C., \& Callan, V.J. (2004). Uncertainty during organizational change: Types, consequences, and management strategies. Journal of Business and Psychology, 18, 507-532.

Brockner, J., \& Higgins, E.T. (2001). Regulatory Focus Theory: Implications for the Study of Emotions at Work. Organizational Behavior and Human Decision Processes, 86, 35-66.

Caldwell S.D., Herold D.M., \& Fedor D.B. (2004). Towards an understanding of the relationships between organizational change, individual differences, and changes in personenvironment fit: A cross-level study. Journal of Applied Psychology, 89, 868-882.

Crowe, E., \& Higgins, E.T. (1997). Regulatory focus and strategic inclinations: Promotion and prevention in decision-making. Organizational Behavior and Human Decision Processes, 69, 117-132.

Cunningham, C.E., Woodward, C.A., Shannon, H.S., MacIntosh, J., Lendrum, B., Rosenbloom, D., \& Brown, J. (2002). Readiness for organizational change: A longitudinal study of workplace, psychological and behavioural correlates. Journal of Occupational and Organizational Psychology, 75, 377-392. 
Demerouti, E. (2006). Job characteristics, flow and performance: The moderating role of conscientiousness. Journal of Occupational Health Psychology, 3, 266-280.

Demerouti, E., Bakker, A.B., Nachreiner, F., \& Schaufeli, W.B. (2001). The job demands-resources model of burnout. Journal of Applied Psychology, 86, 499-512.

Demerouti, E., Bakker, A.B., Vardakou, I., \& Kantas, A. (2003) The convergent validity of two burnout instruments: A multitrait-multimethod analysis. European Journal of Psychological Assessment, 19, 12-23.

Doty, D.H., \& Glick, W.H. (1998). Common methods bias: Does common methods variance really bias results? Organizational Research Methods, 1, 374-406.

Fried, Y. \& Ferris, G.R. (1987). The validity of the Job Characteristics Model: A review and meta-analysis. Personnel Psychology, 40, 287-322.

Fritz, C., \& Sonnentag, S. (2009). Antecedents of day-level proactive behavior: A look at job stressors and positive affect during the workday. Journal of Management, 35, 94111.

Fuller, J.B., Marler, L.E., \& Hester, K. (2006). Promoting felt responsibility for constructive change and proactive behavior: exploring aspects of an elaborated model of work design. Journal of Organizational Behavior, 27, 10891120 .

Hackman, J.R., \& Oldham, G.R. (1980). Work redesign. Reading: Addison-Wesley.

Hakanen, J.J., Bakker, A.B., \& Schaufeli, W.B. (2006). Burnout and work engagement among teachers. Journal of School Psychology, 43, 495-513.

Hakanen, J. J., Perhoniemi, R., \& Toppinen-Tanner, S. (2008) Positive gain spirals at work: From job resources to work engagement, personal initiative and work-unit innovativeness. Journal of Vocational Behavior, 73, 7891.

Higgins, E.T. (1997). Beyond pleasure and pain. American Psychologist, 52, 1280-1300.

Higgins, E.T. (1998). Promotion and prevention: Regulatory focus as a motivational principle. In M. P. Zanna (Ed.), Advances in experimental social psychology (Vol. 30, pp. 1-46). New York: Academic Press.

Higgins, E.T., Roney, C.J., Crowe, E., \& Hymes, C. (1994). Ideal versus ought predictions for approach and avoidance: Distinct self-regulatory systems. Journal of Personality and Social Psychology, 66, 276-286.

Hornung, S., \& Rousseau, D.M. (2007). Active on the job proactive in change: How autonomy at work contributes to employee support for organizational change. Journal of Applied Behavioral Science, 43, 401-426

Janssen, O., \& Van Yperen, N.W. (2004). Employees' goa orientations, the quality of leader-member exchange, and the outcomes of job performance and job satisfaction. Academy of Management Journal, 47, 368-384.

Jimmieson, N.L., Terry, D.J., \& Callan, V.J. (2004). A longitudinal study of employee adaptation to organizational change: The role of change-related information and change-related self-efficacy. Journal of Occupational Health Psychology, 9, $11-27$.

Karasek, R.A. (1979). Job demands, job decision latitude, and mental strain: Implications for job design. Administrative Science Quarterly, 24, 285-308.

Karasek, R. (1985). Job content instrument: Questionnaire and user's guide, revision 1.1. Los Angeles: University of Southern California.

Kark, R., \& van Dijk, D. (2007). Motivation to lead, motivation to follow: The role of the self-regulatory focus in leadership processes. Academy of Management Review, 32, 500528.

Korunka, C., Scharitzer, D., Carayon, P., \& Sainfort, F. (2003). Employee strain and job satisfaction related to an implementation of quality in a public service organization: A longitudinal study. Work E Stress, 17, 52-72.
Kyriacou, C., \& Sutcliffe, J. (1978). Teacher stress: Prevalence, sources, and symptoms. British Journal of Educational Psychology, 48, 159-167.

Latimer, A.E., Rivers, S.E., Rench, T.A., Katulak, N.A., Hicks, A., Hodorowski, J.K., Higgins, E.T., \& Salovey, P. (2008). A field experiment testing the utility of regulatory fit messages for promoting physical activity. Journal of experimental social psychology, 44, 826-832.

Liberman, N., Idson, L.C., Camacho, C.J., \& Higgins, E.T. (1999). Promotion and prevention choices between stability and change. Journal of Personality E Social Psychology, 77, 11351145 .

Lockwood, P., Jordan, C.H., \& Kunda, Z. (2002). Motivation by positive or negative role models: Regulatory focus determines who will best inspire us. Journal of Personality and Social Psychology, 83, 854-864.

Mauno, S., Kinnunen, U., \& Ruokolainen, M. (2007). Job demands and resources as antecedents of work engagement: A longitudinal study. Journal of Vocational Behavior, 70, 149171.

Miller, V.D., Johnson, J.R., \& Grau, J. (1994). Antecedents to willingness to participate in a planned organisational change. Journal of Applied Communication Research, 22, 5980 .

Neubert, M.J., Kacmar, K.M., Carlson, D.S., Chonko, L.B., \& Roberts, J.A. (2008). Regulatory focus as a mediator of the influence of initiating structure and servant leadership on employee behaviour. Journal of Applied Psychology, 93, 12201233.

Noblet, A., Rodwell, J., \& McWilliams, J. (2006). Organizational change in the public sector: Augmenting the demand control model to predict employee outcomes under new public management. Work E Stress, 20, 335-352.

Roney, C., Higgins, E.T., \& Shah, J. (1995). Goals and framing: How outcome focus influences motivation and emotion. Personality and Social Psychology Bulletin, 21, 11511160

Salanova, M., \& Schaufeli, W.B. (2008). A cross-national study of work engagement as a mediator between job resources and proactive behaviour. International Journal of Human Resource Management, 19, 116-131.

Schaufeli, W.B., \& Bakker, A.B. (2004). Job demands, job resources and their relationship with burnout and engagement: $A$ multi-sample study. Journal of Organizational Behavior, 25, 293-315.

Schaufeli, W., \& Enzmann, D. (1998). The burnout companion to stud $y$ and practice: A critical analysis. London: Taylor \& Francis.

Shah, J., Higgins, E.T., \& Friedman, R. (1998). Performance incentives and means: How regulatory focus influences goal attainment. Journal of Personality and Social Psychology, 74, 285-293.

Siegrist, J. (1996). Adverse health effects of high effort-low reward conditions. Journal of Occupational Health Psychology, 1, 27-41.

Strümpfer, D.J. W. (2006). The strengths perspective: Fortigenesis in adult life. Social Indicators Research, 77, 1136.

Tabachnick, B.G., \& Fidell, L.S. (2000). Using multivariate statistics. (4th edn.). London: Allyn \& Bacon.

Taylor-Bianco, A., \& Schermerhorn, J. (2006). Self-regulation, strategic leadership and paradox in organizational change. Journal of Organizational Change Management, 19, 457470.

Tseng, H.C., \& Kang, L.M. (2008). How does regulatory focus affect uncertainty towards organizational change? Leadership E Organization Development Journal, 29, 713-731.

Vakola, M., \& Nikolaou, I. (2005). Attitudes towards organizational change - What is the role of employees' stress and commitment? Employee Relations, 27, 160-174.

Van Horn, J.E., Schaufeli, W.B., \& Enzmann, D. (1999). Teacher burnout and lack of reciprocity. Journal of Applied Social Psychology, 29, 91-108. 
Verhaeghe, R., Vlerick, P., de Backer, G., van Maele, G., \& Gemmel, P. (2008). Recurrent changes in the work environment, job resources, and distress among nurses: A comparative cross-sectional survey. International Journal of Nursing Studies, 45, 382-392.

Wanberg, C.R., \& Banas, J.T. (2000). Predictors and outcomes of openness to changes in a reorganizing workplace. Journal of Applied Psychology, 85, 132-142.
Xanthopoulou, D., Bakker, A.B., Demerouti, E., \& Schaufeli, W.B. (2007). The role of personal resources in the Job DemandsResources model. International Journal of Stress Management, $14,121-141$.

Xanthopoulou, D., Bakker, A.B., Demerouti, E., \& Schaufeli, W.B. (2009). Work engagement and financial returns: A diary study on the role of job and personal resources. Journal of Occupational and Organizational Psychology, 82, 183-200. 